\title{
Laboratory procedures for the isolation of Chlamydia trachomatis from the human genital tract
}

\author{
P. REEVE, J. OWEN, AND J. D. ORIEL
}

From the Departments of Genito-Urinary Medicine and Microbiology, University College Hospital and the Department of Bacteriology, University College Hospital Medical School, London

SYNOPSIS The technique of isolating Chlamydia trachomatis from the human genital tract by centrifuging clinical specimens on to cell monolayers with subsequent incubation has been improved and simplified. Gentamicin in the media was found to be superior to streptomycin in reducing bacterial contamination of specimens. The infectivity of chlamydial suspensions of laboratory cultured material was significantly reduced by storage at $+4^{\circ} \mathrm{C}$ for more than 48 hours, and by immediate freezing to $-70^{\circ} \mathrm{C}$. When compared with immediate processing of the specimens, freezing to $-70^{\circ} \mathrm{C}$ was found to reduce the isolation rate of $C$. trachomatis from men with non-gonococcal urethritis (NGU) by approximately $20 \%$.

McCoy cells pretreated with idoxuridine were compared with irradiated McCoy cells for the isolation of $C$. trachomatis from clinical specimens. There was no significant difference in sensitivity between the two systems, but the former is considerably simpler. The effect of the centrifugal force used for inoculating specimens on to the cell monolayers on the isolation rate of $C$. trachomatis was studied in groups of men with NGU. Maximal isolation rates were obtained with forces of about $3000 \mathrm{G}$, which were not significantly raised by further increasing the force used.

It is suggested that the isolation of $C$. trachomatis from the genital tract is now well within the capacity of any laboratory equipped with simple cell culture facilities.

Non-gonococcal urethritis (NGU) is now one of the commonest sexually transmitted diseases (Department of Health and Social Security, 1974) and a substantial proportion is caused by infection with Chlamydia trachomatis (group A Chlamydia or TRIC agents). Post-gonococcal urethritis (PGU), a related disease, is also in many cases associated with demonstrable chlamydial infection (Richmond et al, 1972; Oriel et al, 1975). In women, C. trachomatis can be recovered from the genital tract of many sexual contacts of men with NGU or gonorrhoea and is also present in a proportion of women in other diagnostic categories (Oriel et al, 1974; Hilton et al, 1974).

There is a growing interest in these microorganisms and several recent advances in culture technique have been made. A cell culture system for the isolation of $C$. trachomatis from clinical specimens was first devised by Gordon and Quan (1965) and slightly modified and simplified by Darougar $e t$ al (1971). In essence, the system involved the centrifugation of specimens on to a monolayer of

Received for publication 19 May 1975. irradiated McCoy cells with subsequent incubation and the demonstration of cytoplasmic inclusions pathognomonic of $C$. trachomatis by staining with Giemsa or iodine. Streptomycin and amphotericin B were used in the transport and growth media to reduce contamination by bacteria and yeasts. Passage of initially Chlamydia-negative specimens was often performed. This method, with minor modifications, has been used by most workers handling specimens from the human genital tract.

Although the system outlined above is greatly superior to previous methods employing culture in the yolk sac of embryonated hens' eggs (Gordon et al, 1967; Dunlop et al, 1971), there is no reason to suppose that it is the definitive method for the isolation of $C$. trachomatis. Difficulties have been encountered in some respects and there is room for simplification in others. These problems may be considered under the following headings.

\section{Contamination of Specimens}

Valid isolation results may not be obtained from some clinical specimens because of contamination by 
yeasts or bacteria. Both Dunlop et al (1972) and Oriel et al (1972) found that approximately $10 \%$ of urethral specimens from men gave invalid results for this reason. In women, Oriel et al (1974) reported that $22 \%$ of cervical specimens were similarly contaminated. Wentworth (1973) suggested that gentamicin and streptomycin together were superior to streptomycin alone as antibacterial agents in transport and growth media; in her hands, their use reduced bacterial contamination from 20 to $8 \%$.

\section{Storage of Clinical Specimens}

Some workers have stored clinical specimens in transport media at $+4^{\circ} \mathrm{C}$ for variable periods of time before the cell cultures are inoculated (Richmond et al, 1972; Oriel et al, 1972) and others have snap-frozen specimens to $-70^{\circ} \mathrm{C}$ (Darougar et al, 1971). There is some uncertainty as to which of these methods is preferable and how long specimens can be kept at either temperature without significant loss of infectivity.

\section{Choice of Cell Lines}

Although there is a general belief that irradiated McCoy cells possess some special advantage for the isolation of $C$. trachomatis, there have been few controlled studies to support this. It is worth noting that the McCoy cell is not, as commonly supposed, a human synovial cell; it is probably a mouse L-cell (Blyth and Taverne, 1974). Unirradiated BHK 21 cells (Blyth and|Taverne, 1974), HELA 229 cells (Kuo et al, 1972), and unirradiated McCoy cells (Hobson et al, 1974) have all been used successfully for the isolation of $C$. trachomatis. Blyth and Taverne (1974) have discussed the necessary preconditions for isolation work. The important factor seems to be the use of stationary phase cells; irradiation or the use of confluent cultures and low serum media can all inhibit growth to provide suitable cell cultures.

The irradiation of McCoy cells requires equipment which is not always available. Wentworth and Alexander (1974) have recently indicated that large stationary phase cells with abundant cytoplasm can be obtained by the treatment of McCoy cells with idoxuridine. Their studies with clinical specimens indicate that idoxuridine-treated cells, when used for the isolation of $C$. trachomatis, give results which are not inferior to those obtained with irradiated McCoy cells.

\section{Speed of Centrifugation}

C. trachomatis from clinical' specimens will not infect cells unless a centrifugal force is applied. Reeve and Taverne (1967) demonstrated a linear relationship between the number of inclusions seen in cell monolayers infected with a standard inoculum and the centrifugal force applied. Maximum inclusion counts were obtained at about $4000 \mathrm{G}$. Darougar et al (1974), using material obtained from clinical specimens, have recently reported similar observations. Such studies do not necessarily imply that the actual rate of isolation of $C$. trachomatis from clinical material will be related to the centrifugal force used, as only specimens with a small content of infective material are likely to give a positive isolation result only after high-speed centrifugation. If such specimens comprised a significant proportion of the whole, the use of high speeds might result in an increase in the isolation rate. In the published studies of the isolation of $C$. trachomatis from specimens from the genital tract, relatively low centrifugal forces $(1800-2500 \mathrm{G})$ have been applied (Darougar et al, 1971; Oriel et al, 1972; Richmond et al, 1972). Clearly, the optimum force required is in need of definition.

In the present investigation we have studied (1) the effect of gentamicin in transport and growth media in reducing the contamination of clinical specimens; (2) the effect of storage at $+4^{\circ} \mathrm{C}$ and $-70^{\circ} \mathrm{C}$ on the infectivity of a laboratory strain of $C$. trachomatis and on the recovery of $C$. trachomatis from clinical specimens; (3) the comparison of irradiated McCoy cells with idoxuridine-treated McCoy cells for the isolation of $C$. trachomatis; and (4) the effect of increasing centrifugal forces applied to cell monolayers on the isolation of $C$. trachomatis from genital tract specimens from groups of patients in the same diagnostic category. Our objectives have been to define procedures for the isolation of $C$. trachomatis which are sensitive yet require only equipment which is already available in the majority of clinical microbiology laboratories.

\section{Material and Methods}

\section{PATIENTS}

Clinical specimens were obtained from men and women who attended the Department of GenitoUrinary Medicine, University College Hospital during 1974. Urethral specimens from men with NGU were taken with a wire cotton-wool tipped endourethral swab (Medical Wire \& Equipment Co) inserted $3-4 \mathrm{~cm}$ into the urethra without anaesthesia. Specimens from an unselected group of women who were attending the department for the first time were obtained by inserting a wooden cotton-wool tipped swab into the cervical canal. 
CELL CULTURES

McCoy cells were grown in a growth medium; Eagle's minimal essential medium supplemented by the addition of fetal calf serum $10 \% \mathrm{v} / \mathrm{v}$, glutamine $1 \% \mathrm{v} / \mathrm{v}$ of stock $(30 \mathrm{mg} / \mathrm{ml}$ ), and vitamins (Flow laboratories $100 \times$ concentrate) $1 \% \mathrm{v} / \mathrm{v}$, to which was added amphotericin B (tissue culture grade) $2.5 \mu \mathrm{g} / \mathrm{ml}$ and either streptomycin $10 \mu \mathrm{g} / \mathrm{ml}$ or gentamicin $10 \mathrm{IU} / \mathrm{ml}$.

When confluent, the McCoy cells were treated in one of two ways:

(1) The cells were subjected to $6000 \mathrm{r}$ of X-irradiation given over 11 minutes. Five to seven days later, the cells were suspended and diluted in growth medium to $10^{5}$ cells $/ \mathrm{ml}$, and $1 \mathrm{ml}$ of this suspension was added to each of a series of flat-bottomed $10 \mathrm{ml}$ plastic tubes containing a $12 \mathrm{~mm}$ diameter coverslip; two days later the cells were ready for use.

(2) The cells were seeded into $10 \mathrm{ml}$ plastic tubes as before but using as a diluent growth medium containing 5-iodo 2 ' deoxyuridine (IUDR), $25 \mu \mathrm{g} / \mathrm{ml}$; tubes were used for isolation attempts between three and seven days after seeding.

\section{ISOLATION PROCEDURES}

Swabs collected as described above were broken into bijoux containing $2 \mathrm{ml}$ growth medium supplemented with glucose $0.05 \mathrm{M}$ and were either stored at $+4^{\circ} \mathrm{C}$ or snap-frozen to $-70^{\circ} \mathrm{C}$. For inoculation, the growth medium was removed from each of two $10 \mathrm{ml}$ tubes containing cell monolayers and replaced by $1 \mathrm{ml}$ of specimen. These inoculated tubes were centrifuged in an MSE Super Minor centrifuge or a Baird \& Tatlock bench centrifuge (for centrifugal forces up to $2750 \mathrm{G}$ ) or in a Sorvall RC2B machine (for forces up to $6000 \mathrm{G}$ ) at temperatures of approximately $35^{\circ} \mathrm{C}$ for one hour. They were then incubated at $35^{\circ} \mathrm{C}$ for 48 hours. The cells were then fixed with methanol and stained with Lugol's iodine in the tubes. The supernatant was drawn off and the coverslip was removed by inserting a hot wire

\begin{tabular}{|c|c|c|c|c|}
\hline \multirow[t]{2}{*}{ Source of Specimens } & \multirow{2}{*}{$\begin{array}{l}\text { Antibiotic used } \\
\text { in Media }\end{array}$} & \multirow{2}{*}{$\begin{array}{l}\text { No. of } \\
\text { Specimens }\end{array}$} & \multicolumn{2}{|c|}{ Contaminated } \\
\hline & & & No. & $\%$ \\
\hline $\begin{array}{l}\text { Men with NGU } \\
\text { (urethra) }\end{array}$ & $\begin{array}{l}\text { Streptomycin }{ }^{1} \\
(10 \mu g / m \mathrm{~m}) \\
\text { Gentamicin } \\
(101 \mathrm{U} / \mathrm{ml})\end{array}$ & $\begin{array}{l}105 \\
108\end{array}$ & $\begin{array}{l}7 \\
8\end{array}$ & $\begin{array}{l}7 \\
7\end{array}$ \\
\hline $\begin{array}{l}\text { Unselected women } \\
\text { (cervix) }\end{array}$ & $\begin{array}{l}\text { Streptomycin }{ }^{1} \\
(10 / \mu g / m l) \\
\text { Gentamicin } 1 \\
(10 \mathrm{IU} / \mathrm{ml})\end{array}$ & $\begin{array}{l}318 \\
642\end{array}$ & $\begin{array}{l}71 \\
75\end{array}$ & 12 \\
\hline
\end{tabular}

Table I Effect of antibiotics in transport and growth media on contamination of genital tract specimens for Chlamydia isolation

${ }_{1}^{1}$ Also contained amphotericin B, $2.5 \mu \mathrm{g} / \mathrm{ml}$. through the base of the tube. The coverslips were dried on blotting paper, mounted in oil, and examined at $\times 300$ magnification. Cytoplasmic inclusions pathognomonic of $C$. trachomatis are seen as large, red-brown staining granular masses. Inclusions can be stained with Giemsa and examined by direct or dark-field illumination, but we have found no particular advantage in this technique and prefer the simpler method of iodine staining.

Plastic tubes were obtained from G. K. Searle (High Wycombe) Ltd, coverslips from Solmedia Ltd, London E17, and IUDR from Sigma (London) Ltd.

\section{Results}

\section{EFFECT OF GENTAMICIN IN REDUCING} CONTAMINATION

Urethral specimens were obtained from two groups of men with NGU: (1) a group of 105 men studied at St Thomas' Hospital who have already been described (Oriel et al, 1972). The media contained streptomycin $10 \mu \mathrm{g} / \mathrm{ml}$; (2) a group of 108 men seen at University College Hospital, where the media contained gentamicin $10 \mathrm{IU} / \mathrm{ml}$. Contaminated specimens were obtained from seven men in group 1 $(6.7 \%)$ and from eight men in group $2(7.4 \%)$. Thus for examination of these specimens from meno gentamicin did not appear to be superior to strepto mycin in reducing contamination (table $\mathrm{I}$ ).

However, in specimens from women the use of gentamicin in the media appeared to reduce significantly the number of contaminated specimens. A group of 318 unselected women at St Thomas' Hospital (Oriel et al, 1974), whose cervical specimens were examined in streptomycin-containing media, yielded 71 contaminated specimens $(22 \%)$, but a similar group of 642 women seen at University College Hospital during the present investigation yielded contaminated specimens in only 75 cases $(12 \%)$ (table I).

\section{EFFECT OF STORAGE}

In order to assess the effects of storage on the infectivity of $C$. trachomatis, suspensions of the SA2f strain cultured in ovo were either stored at $+4^{\circ} \mathrm{C}$ or frozen to $-70^{\circ} \mathrm{C}$, and infectivity was measured by counting the number of inclusions formed after incubation in idoxuridine-treated McCoy cell monolayers (Furness et al, 1960). Over 80\% infectivity was lost after storage at $+4^{\circ} \mathrm{C}$ for 48 hours (table II), and thereafter infectivity continued to diminish A similar drop in initial infective titre was seen in material frozen at $-70^{\circ} \mathrm{C}$ and subsequently thawed to allow titration in cell monolayers. Prolonged storage at $-70^{\circ} \mathrm{C}$, however, did not result in further losses. 


\begin{tabular}{lll}
\hline No. of Days & \multicolumn{2}{l}{ No. of Inclusions per Coverslip } \\
\cline { 2 - 3 } Stored & Storage at $+4^{\circ} \mathrm{C}$ & Storage at $-70^{\circ} \mathrm{C}$ \\
\hline 0 & 195 & 180 \\
1 & 72 & 31 \\
2 & 32 & 42 \\
3 & 10 & 27 \\
4 & 0 & Not done \\
5 & 0 & 36 \\
6 & 0 & 26 \\
\hline
\end{tabular}

Table II Effect of storage at $+4^{\circ} \mathrm{C}$ and $-70^{\circ} \mathrm{C}$ of Chlamydia trachomatis (strain $S A 2 F 10 \%$ w/v yolk sac suspension in tissue culture growth medium)

To assess the significance of loss of infectivity from freezing and thawing on actual isolation rates from clinical material, specimens were obtained from 80 men with NGU and assayed for infectivity within a few hours and again after a portion of the clinical specimen had been frozen to $-70^{\circ} \mathrm{C}$. Of 40 specimens which yielded $C$. trachomatis initially, 33 $(83 \%)$ were still infective after freezing and thawing. The numbers of inclusions seen in the cell cultures which gave positive results were counted as a measure of the infectivity of the specimens. The mean inclusion counts were always greater in cells inoculated with the unfrozen specimens.

It was concluded that ideally specimens should be processed within a few hours of collection, which is the procedure we now adopt. Storage for up to 48 hours at $+4^{\circ} \mathrm{C}$ gives adequate results but for storage beyond this time freezing to $-70^{\circ} \mathrm{C}$ is necessary. Both these latter procedures, however, will lead to a loss in demonstrable infectivity of about $20 \%$.

\section{USE OF MCCOY CELLS TREATED WITH} IDOXURIDINE

The sensitivity of McCoy cells pretreated with idoxuridine was compared with irradiated McCoy cells by attempting isolations of $C$. trachomatis from duplicate specimens collected from the cervix of a group of women who were sexual contacts of men with NGU. The duplicate cervical specimens were handled identically up to the stage of inoculation of the cell monolayers.

The results show that there is no significant difference in sensitivity between the two cell culture systems. Specimens from 81 women were examined; isolates of $C$. trachomatis were obtained from 26 women using idoxuridine-treated cells and from 24 women using irradiated cells. The numbers of specimens examined were insufficient to indicate whether the new method is more sensitive than the old, but it is certainly no less sensitive, and it is considerably simpler.
EFFECT OF CENTRIFUGAL FORCE

We examined urethral specimens from successive groups of men with NGU after incubation on idoxuridine-treated McCoy cells, using centrifugal forces of $600,1800,2750$, and $6000 \mathrm{G}$. For the first four forces we used bench centrifuges manufactured by MSE and by Baird \& Tatlock. Specimens exposed to a force of $6000 \mathrm{G}$ were centrifuged in a Sorvall/ RB4 machine. All specimens were centrifuged for one hour at a temperature of approximately $35^{\circ} \mathrm{C}$.

The results (figure) indicate that below about

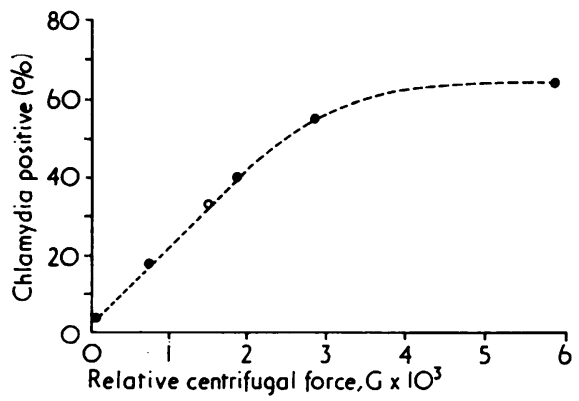

Figure Relationship between the isolation of C. trachomatis from urethral specimens obtained from men with NGU and the centrifugal force applied to infect cell cultures. Specimens in Eagle's growth medium were centrifuged on to McCoy cell monolayers and centrifuged at the forces indicated: data obtained during the present study; $\bigcirc$ data already published (Oriel et al, 1972).

$2500 \mathrm{G}$ the isolation rates were proportional to the centrifugal force used. At about $3000 \mathrm{G}$, however, maximal isolation rates were obtained which were not significantly raised by increasing the centrifugal force to $6000 \mathrm{G}$.

\section{Discussion}

We have found the method described above with the modifications we have suggested to be simple, reliable, and effective. Provided that attention is paid to detail, the isolation of $C$. trachomatis should prove no more difficult than the isolation of other common genital pathogens such as Neisseria gonorrhoeae or Herpesvirus simplex. The use of gentamicin in place of streptomycin in the media does not appear to reduce contamination of urethral specimens from men but does seem to reduce significantly the numbers of contaminated specimens obtained from women, and for routine use we therefore think that gentamicin is preferable. 
Our results indicate that clinical specimens can be kept at $+4^{\circ} \mathrm{C}$ for 48 hours but that after this time freezing to $-70^{\circ} \mathrm{C}$ is necessary. However, freezing and subsequent thawing for isolation attempts does reduce the infectivity of chlamydial suspensions (whether obtained from urethral specimens or from laboratory cultured material) by about one-third, and this may result in a lowered isolation rate from clinical specimens of about $20 \%$.

The pretreatment of McCoy cells with idoxuridine rather than with irradiation marks a welcome simplification of technique. Many laboratories have found irradiation a difficult procedure, and pretreatment of cells with idoxuridine not only presents no technical difficulties but provides a cell line which is no less sensitive for the isolation of C. trachomatis.

We believe that the optimum centrifugal force required for inoculation of the cell monolayers is about $2750 \mathrm{G}$, which is readily obtainable with small bench centrifuges run at maximum speeds. The use of higher forces (6000 $\mathrm{G}$ and above) requires more complex machines not always available in routine laboratories and moreover reduces the number of specimens which can be handled at any one time. We have found no evidence that use of these higher centrifugal forces materially increases the isolation rate.

We have attempted to show that the isolation of C. trachomatis does not require complex procedures only available in the research laboratory; it is well within the capacity of any laboratory equipped with simple cell culture facilities. However, it must not be forgotten that any laboratory procedure is only as good as the specimens submitted for examination, and that for the isolation of $C$. trachomatis careful collection and handling of specimens by the clinician is of no less importance than the work performed by the microbiologist.

We are grateful to Dr E. Joan Stokes for help and encouragement and especially for providing laboratory facilities, and to Miss Lam Po Tang for technical assistance. This work was supported by a grant from the Medical Research Council.

\section{References}

Blyth, W. A. and Taverne, J. (1974). Cultivation of TRIC agents; a comparison between the use of BHK-21 and irradiated McCoy cells. J. Hyg. (Lond.), 72, 121-128.

Darougar, S., Cubitt, S., and Jones, B. R. (1974). Effect of high-speed centrifugation on the sensitivity of irradiated McCoy cell culture for the isolation of Chlamydia. Brit. J. vener. Dis., 50, 308-312.
Darougar, S., Kinnison, J. R., and Jones, B. R. (1971). Simplified irradiated McCoy cell culture for isolation of Chlamydia. In Trachoma and Related Disorders, edited by R. L. Nichols, pp. 63-70. Excerpta Medica, Amsterdam and London.

Department of Health and Social Security (1974). On the State of the Public Health: The Annual Report of the Chief Medical Officer of the Department of Health and Social Security for the Year 1973, pp. 3 and 48. HMSO, London.

Dunlop, E. M. C., Freedman, A., Garland, J. A., Harper, I. A., Jones, B. R., Race, J. W., du Toit, M. S., and Treharne, J. D. (1967). Infection by Bedsoniae and the possibility of spurious isolation. 2. Genital infection, disease of the eye, Reiter's disease. Amer.J. Ophthal., 63, 1073-1081.

Dunlop, E. M. C., Hare, M. J., Darougar, S., and Jones, B. R. (1971). Chlamydial infection of the urethra in men presenting because of 'non-specific' urethritis. In Trachoma and Related Disorders, edited by R. L. Nichols, pp. 494500. Excerpta Medica, Amsterdam and London.

Dunlop, E. M. C., Vaughan-Jackson, J. D., Darougar, S., and Jones, B. R. (1972). Chlamydial infection. Incidence in 'non-specific' urethritis. Brit. J. vener. Dis., 48, 425-428.

Furness, G., Graham, D. M., and Reeve, P. R. (1960). The titration of trachoma and inclusion blenorrhoea viruses in cell cultures. J. gen. Microbiol., 23, 613-619.

Gordon, F. B., Dressler, H. R., and Quan, A. L. (1967). Relative sensitivity of cell culture and yolk sac for detection of TRIC infection. Amer. J. Ophthal., 63, 1044-1048.

Gordon, F. B. and Quan, A. L. (1965). Isolation of the trachoma agent in cell culture. Proc. Soc. exp. Biol. (N.Y.), 118, 354-359.

Hilton, A. L., Richmond, S. J., Milne, J. D., Hindley, F., and Clarke, S. K. R. (1974). Chlamydia A in the female genital tract. Brit. J. vener. Dis., 50, 1-10.

Hobson, D., Johnson, F. W. A., Rees, E., and Tait, I. A. (1974). Simplified method for diagnosis of genital and ocular infections with Chlamydia. Lancet, 2, 555-556.

Kuo, C. C., Wang, S. P., Wentworth, B. B., and Grayston, J. T. (1972). Primary isolation of TRIC organisms in HeLa 229 cells treated with DEAE-Dextran. J. infect. Dis., 125, 665-668.

Oriel, J. D., Powis, P. A., Reeve, P., Miller, A., and Nicol, C. S. (1974). Chlamydial infections of the cervix. Brit. J. vener. Dis., 50, 11-16.

Oriel, J. D., Reeve, P., Powis, P. A., Miller, A., and Nicol, C. S. (1972). Chlamydial infection. Isolation of Chlamydia from patients with non-specific genital infection. Brit. $J$. vener. Dis., 48, 429-436.

Oriel, J. D., Reeve, P., Thomas, B. J., and Nicol, C. S. (1975). Infection with Chlamydia Group A in men with urethritis due to Neisseria gonorrhoeae. J. infect. Dis., 131, 376,

Reeve, P. and Taverne, J. (1967). Strain differences in the behaviour of TRIC agents in cell cultures. Amer. J. Ophthal., 63, 1167-1173.

Richmond, S. J., Hilton, A. L., and Clarke, S. K. R. (1972). Chlamydial infection. Role of Chlamydia subgroup $\mathbf{A}$ in non-gonococcal and post-gonococcal urethritis. Brit. J. vener. Dis., 48, 437-444.

Wentworth, B. B. (1973). Use of gentamicin in the isolation of subgroup A Chlamydia. Antimicr. Agents Chemother., 3, 698-702.

Wentworth, B. B. and Alexander, E. R. (1974). Isolation of Chlamydia trachomatis by use of 5-iodo-2-deoxyuridinetreated cells. Appl. Microbiol., 27, 912-916. 